OIKOS

November 2000; 91(2) : 255-270

http://dx.doi.org/10.1034/j.1600-0706.2000.910206.x

(c) Blackwell Publishing, Inc.

The definitive version is available at www.blackwell-synergy.com
Archimer http://www.ifremer.fr/docelec/ Archive Institutionnelle de l'Ifremer

\title{
Comparative analysis of phylogenetic and fishing effects in life history patterns of teleost fishes
}

\author{
Marie-Joëlle Rochet ${ }^{\mathrm{a}}{ }_{\star}$, Pierre-André Cornillon $^{\mathrm{b}}{ }$, Robert Sabatier ${ }^{\mathrm{c}}$ and Dominique Pontier ${ }^{\mathrm{d}}$ \\ a Laboratoire MAERHA, IFREMER, Rue de l'Ile d'Yeu, B.P. 21105, F-44311 Nantes Cedex 03, France \\ ${ }^{b}$ P.-A. Cornillon, CIRAD-Forêt, BP 1291, Pointe Noire, Congo \\ ${ }^{\mathrm{c}}$ R. Sabatier, UMR 9921 Immunoanalyse et Innovation en Biologie Clinique, Université Montpellier I, Avenue C. \\ Flahault, F-34060 Montpellier Cedex 1, France. \\ d D. Pontier, UMR CNRS no. 5558 Biométrie, Génétique et Biologie des Populations, Université Claude Bernard \\ LYON 1, 43 boulevard du 11 novembre 1918, F-69622 Villeurbanne Cedex, France. \\ *mjrochet@ifremer.fr
}

\begin{abstract}
The effects of fishing on life history traits and life history strategies of teleost fishes are analysed by a new comparative method that splits traits into an allometric part (size effect), an autoregressive phylogenetic component, and an environmental component (fishing effect). Both intraand inter-specific variation of age and size at maturity, fecundity, adult size and egg size are analysed by comparing 84 populations of 49 species submitted to various fishing pressures. Two axes of life history diversification are found among teleosts. One is the well-known slow-fast continuum separating short-lived and early maturing species (like Clupeiformes) from longer-lived species that mature late relative to their size and spawn larger eggs (like salmonids or Scorpaeniformes). An additional strategy involves the schedule of resource allocation to growth and reproduction. Indeterminate growth allows higher teleosts (e.g. Gadiformes) to reach a large size while maturing early and laying small eggs. Increasing fishing pressure decreases age at maturity and egg size, and increases fecundity at maturity, the slope of the fecundity-length relationship and relative size at maturity. These compensations for higher adult mortality differ among life history strategies. Indeterminate growth is associated with a greater flexibility in resource allocation to growth and reproduction that facilitates greater resilience to fishing mortality.
\end{abstract}

Keywords: angling, ecosystem management, freshwater fisheries, habitat rehabilitation, recreational fisheries, stocking 


\section{Introduction}

The modern comparative approach has provided a powerful tool for understanding the patterns of life history variation in an evolutionary perspective (Harvey and Pagel 1991, Martins and Hansen 1997). It may also have implications in population management and conservation (Winemiller and Rose 1992, Jennings et al. 1998). Most empirical results and methodological developments in this field have been based on species or higher-order taxa comparisons, where taxa are described by a single value of life history traits (e.g. Western 1979, Stearns 1983, Gaillard et al. 1989, Promislow and Harvey 1990, Winemiller and Rose 1992, Clobert et al. 1998). Each taxon point corresponds to an average across populations, or is based on a single study case. Essentially, this assumes that intraspecific variation in life history traits is insignificant compared to interspecific variability. However, long-term studies of several vertebrate populations have generated important findings about life history trait variation at the intraspecific level (Leggett and Carscadden 1978, Jennings and Beverton 1991, Roff 1991, Boake 1994, McNamara and Houston 1996, Reznick et al. 1996, Gaillard et al. 1998). Ignoring intraspecific variation may limit our evolutionary insight of processes, or, worse, lead to flawed interpretation of the observed patterns (Foster and Cameron 1996). Moreover, theories of life history evolution are explicitly micro-evolutionary (Roff 1992, Stearns 1992, Bauwens and DiazUriarte 1997). The inclusion of intra-specific variation in comparative analyses across species may also help to link macro-evolutionary patterns and the mechanistic models of life history evolution.

Fishes offer a good model to examine both intra- and inter-specific variability of life history traits because a large diversity of species are submitted to a strong environmental constraint due to exploitation. In addition, for management purposes, many commercially exploited populations have been monitored. This provides a suitable material to re-examine the patterns of covariation of life history traits in fishes.

There are several ways in which populations can respond both phenotypically and evolutionarily to the reduction in adult survival caused by size-selective harvesting (Stokes et al. 1993). They include reproduction, growth and survival patterns (see review in Jennings and Kaiser 1998). Life-history theory predicts that increased mortality in the older age classes should select for a lower age at first reproduction and increased reproductive effort at all ages before the afflicted age 
class (Gadgil and Bossert 1970, Schaffer 1974, Law 1979, Michod 1979, Charlesworth 1994). Also, removal of larger and faster-growing animals will select for a slower growth to a smaller size (Kirkpatrick 1993, Law and Rowell 1993). On the other hand, because of reduced abundance caused by fishing, we expect intraspecific competition to be reduced. As fish growth is highly sensitive to resource availability (Borisov 1979, McKenzie et al. 1983, Jones 1989, Frank and Leggett 1994, Rijnsdorp 1994), a lower density may increase growth rates. These may in turn result in changes in reproduction, for example earlier maturity or higher fecundity, due to the strong size-dependence of these traits (Reznick 1993).

In exploited populations, the knowledge of the nature and magnitude of these changes may have important implications for stock assessment and management: management strategies may be adapted to population responses. The existence of fishing effects on life history traits is well documented in literature (e.g. Nelson and Soulé 1987, Trippel 1995, Trippel et al. 1997). However, the effects of fishing are difficult to measure because they are often confounded with other environmental changes (e.g. changes in temperature or other species in the community) and cannot be separated in statistical analysis of single-species time series (Pitt 1975, Hempel 1978, Rijnsdorp et al. 1991, Rijnsdorp and van Leeuwen 1992). Therefore, a comparative approach involving many populations seems appropriate.

Life history strategies of fishes have been examined extensively in the past, but most comparative studies neglected both phylogenetic effects and intraspecific variation (Beverton and Holt 1959, Beverton 1963, Murphy 1968, Pauly 1980, Roff 1984, Hutchings and Morris 1985, Gunderson and Dygert 1988, Winemiller 1989, Jennings and Beverton 1991, Roff 1991, Beverton 1992, Winemiller and Rose 1992, Gunderson 1997, McCann and Shuter 1997). Here our goals are to i) better characterise life history patterns within a group of teleost fishes, ii) assess the magnitude of fishing effects on life history traits, iii) determine whether the slow-fast continuum observed in birds and mammals (Gaillard et al. 1989, Promislow and Harvey 1990) and in lizards (Shine and Charnov 1992, Clobert et al. 1998) can be extended to fishes, iv) examine whether the decrease of adult survival due to fishing moves species towards the fast end of the continuum, irrespective of their position along this continuum. For that purpose, we developped a new comparative method designed to incorporate both inter- and intra-specific variation in life history traits (Cornillon et al. 2000). This method is based 
on autoregressive methods whose aim is to separate environmental effects from phylogenetic influence (Cheverud et al. 1985, Gittleman and Kot 1990). We used this method to analyse data on six life-history traits: age and size at maturity, fecundity, adult survival, adult size and egg size, for 84 populations belonging to 49 species that vary in the intensity of fishing pressure experienced.

\section{Materials and methods}

\section{1) Demographic traits}

We gathered published data of age-specific mortality rates, age-specific lengths or weights, length and age at maturity, fecundity-length relationships, and egg size for 84 populations from 49 species of primarily commercial teleost fishes. Because fishes may respond very quickly to fishing, we selected populations for which all the life history traits under study have been estimated over a period shorter than 10 years. Traits were estimated from within the ten-year window, or averaged across it when data were available. We selected studies in which reference population, sample size, techniques used for ageing fish and counting eggs, and models used for estimating mortality are described.

When only a size or age range was available, we used the midpoint between the extreme values.

Raw data were converted into seven demographic traits:

- Time-to-5\%-survival $\left(\mathrm{T}_{.05}\right)$ : we define it as the time elapsed from sexual maturity until 95\% of a cohort is dead. Maximum observed age, usually used in comparative studies of fishes (Beverton and Holt 1959, Murphy 1968, Mann et al. 1984, Roff 1984, Hutchings and Morris 1985, Jennings and Beverton 1991, Beverton 1992), was discarded because this parameter is highly dependent on sample size (Hoenig 1983, Zammuto 1986). Other studies have compared adult mortality rates (Promislow and Harvey 1990, Shine and Charnov 1992, Shine and Iverson 1995, Clobert et al. 1998), but these may vary among age classes in fishes. Therefore we used time-to-5\%-survival because it integrates mortality rates over most adult life. We estimated $\mathrm{T}_{.05}$ from an exponential mortality model, based on total mortality coefficients estimated by Virtual Population Analysis (age-structured model) in most cases or cohort analysis or catch curves (Beverton and Holt 1957).

- Length-at-5\%-survival $\left(\mathrm{L}_{.05}\right)$ : in fishes, adult size is difficult to measure because of their indeterminate growth. We arbitrarily measure adult size at time-to- $5 \%$-survival rather than using the 
two more common measures, maximum length and asymptotic size. Maximum observed length (e.g. Hutchings and Morris 1985, Winemiller and Rose 1992) has the same disadvantages as maximum age. Asymptotic size, the L $\infty$ parameter of the von Bertalanffy (1934) growth model, is the most commonly used adult-size parameter in comparative studies of growth or size in fishes (Beverton and Holt, 1959; Beverton, 1963; Adams, 1980; Pauly, 1980; Roff, 1984; Gunderson and Dygert, 1988; Jennings and Beverton, 1991; Roff, 1991; Beverton, 1992; Gunderson, 1997), but Knight (1968) pointed out the spuriousness of comparing asymptotic sizes when they are extrapolated from truncated growth data: L $\infty$ estimates have a very high sampling error. This is especially true for exploited populations, where old individuals are scarce.

- Age at sexual maturity $\left(T_{m}\right)$ : we used median age at maturity, estimated directly from the data or by fitting a logistic curve to age-specific, proportion-mature data. When only an age range was available, we used the midpoint between minimum and maximum.

- Length at sexual maturity $\left(\mathrm{L}_{\mathrm{m}}\right)$ : we used median length at maturity, estimated like age at maturity. To the extent possible, we used separate estimates of length and age at maturity, but in some cases we had to use length at age data to convert age to length at maturity or the reverse. The ratio of length at maturity to final length has been frequently shown to be constant within taxonomic groups of fishes (Beverton 1963, Ware 1980, Beverton 1992). Therefore, we also considered $\mathrm{L}_{\mathrm{rm}}$, the relative length at maturity, which we define as the ratio of median length at maturity to length-at- $5 \%$ survival, as an index of the proportion of growth achieved at maturity.

- Slope of the fecundity-length relationship $\left(\mathrm{F}_{\mathrm{b}}\right)$ : fish fecundity, defined as the number of eggs present in the ovaries immediately before spawning, is known to increase intraspecifically with the size of females (Fulton 1891). This increase is usually described by a power-law $\mathrm{F}=\mathrm{aL}^{\mathrm{b}}$ (Raitt 1932). The exponent of this relationship, $b$ (slope of the log-log fecundity-length regression), accounts for the increase in fecundity with size.

- Fecundity at maturity $\left(\mathrm{F}_{\mathrm{m}}\right)$ : fecundity in the year of maturity was estimated from length at maturity, the fecundity-length relationship and the number of spawning bouts per year for batch spawners. $\mathrm{F}_{\mathrm{m}}$ is a potentially important component of fish response to fishing because of the high contribution of first spawners to population fecundity in heavily exploited stocks. 
- Egg volume (Egg): in teleosts a trade-off exists between fecundity and egg size both intraand interspecifically (e.g. Mann and Mills 1979, Wootton 1979, Roff 1982, Elgar 1990, Rijnsdorp 1993); hence the variations in fecundity cannot be interpreted without reference to egg size. When information on egg size was unavailable in specific papers, we referred to reference manuals or papers, using the following criteria in the descending order: from the same period, the same population, the same species. In five species of Perciformes, no estimate was available for any population, thus egg volume was estimated from other species of the same family.

The data and their references are available from the first author or on web-site http://www.ifremer.fr/maerha.

\section{2) Fishing pressure}

To contrast the environments of the populations, we defined three types of environments with low, moderate and high fishing pressure.

To scale the pressure exerted by fishing to the natural population turn-over, it was expressed as the ratio of fishing mortality to natural mortality rates $(\mathrm{F} / \mathrm{M})$. Data were gathered from the literature together with demographic traits. Authors use the following methods to estimate natural mortality rates: intercept of a regression of total mortality on fishing effort (Cushing 1981), linear relationship known between estimates of natural mortality, growth parameters and the temperature (Pauly 1980), or multispecies models (Sparholt 1990). Fishing mortality rates are estimated from Virtual Population Analysis or cohort analysis. Alternatively, total mortality rates are estimated by catch-curve methods and fishing mortality is derived as the difference between total and natural mortality. We defined three levels of fishing pressure: low fishing pressure (fishing mortality lower than natural mortality, $\mathrm{F} / \mathrm{M}<1)$, intermediate $(1 \leq \mathrm{F} / \mathrm{M}<2)$ and high $(\mathrm{F} / \mathrm{M} \geq 2)$. Fishing pressure is independent of taxonomic position, and as a result, the groups of fishing pressure are evenly distributed across broad taxonomic groups (Fig. 1). Argentiniformes and Atheriniformes are the two orders with all populations (respectively 4 and 2) submitted to the same fishing pressure.

\section{3) Phylogenetic information}

Phylogenetic relationships were compiled from the most recent information available for teleost fishes (Eschmeyer 1990, Lecointre 1994, Nelson 1994, Johnson and Patterson 1996) (Fig. 1). We 
collated partial phylogenetic trees, based on morpho-anatomical characters and on molecular traits. The resulting tree can be considered as a consensus tree summarising present knowledge about teleosts interrelationships. As data were obtained from different sources by various methods, estimates of branch lengths are not available for all parts of the tree; where they are available, they are not comparable. More basically, the use of either fossil or molecular data to estimate distances between taxa relies on the hypothesis that all traits evolve at the same rate along all branches. But evolutionary rates are known to vary among traits (Brower et al. 1996, Svensson 1997). For a given trait, evolutionary rates vary between branches of a phylogenetic tree (Aota and Ikemura 1986, Britten 1986, Catzeflis et al. 1987, Li et al. 1996, Mindell and Thacker 1996), and they also vary with time along a given branch (Svensson 1997). We considered only the topology of the phylogenetic tree, and set branch lengths equal for the whole tree. We used intermediate nodes along branches to permit insertion of new populations without changing distances in the whole tree (Fig. 1). This is an arbitrary choice, but not more arbitrary than using branch length estimates that are almost certainly flawed estimates of the amount of evolutionary change.

As we compare populations within species, our phylogenetic tree includes a population level. All intraspecific distances were also assumed constant, because no estimate of genetic distances between populations was available. However, populations within species have been diverging evolutionarily for substantially less time than different species have been diverging. Moreover, populations are not separate evolutionary entities, due to gene flow. Therefore, inter- and intraspecific variations cannot be treated in the same way. This problem is addressed with the statistical model.

\section{4) Testing for phylogenetic effects}

When dealing with comparative data the first step is often to test whether the traits demonstrate phylogenetic effects, i.e. whether closely related species tend to be similar phenotypically (Gittleman and Kot 1990, Björklund 1997). If the data are thought to have no phylogenetic effects, then the observations are said to be independent $\left(H_{0}\right)$, otherwise they are influenced by the phylogenetic tree $\left(H_{1}\right)$. Assumptions needed to derive the distribution of test statistics are directly linked to 
models supposed to be true under $H_{0}$. Moreover, the power of the test is determined by $H_{1}$, which is not entirely specified: we only know that independence of observations is not satisfied.

As the information required for a classical test is not available, we used an alternative approach: first defining models with and without phylogenetic effects, then conducting a statistical choice between them, as suggested by Martins and Hansen (1997).

\section{5) A family of autoregressive models}

Let $y$ denote a variable observed for $n$ populations and $y_{i}$ the measure for the $i^{\text {th }}$ population. As described in Cheverud et al. (1985) and Lynch (1991), we assumed that each demographic trait can be split into several parts: the phylogenetic effect $Z$; a regression-like term which accounts for $r$ covariables $L$ (for example body size); the third part can be called the environmental-residual part $\varepsilon$. The full model can be stated as

$$
y_{i}=z_{i}+L_{i} \gamma+\varepsilon_{i}
$$

We assumed an additive model without interaction, meaning that each effect acts independently. As most life history traits are affected by body size (Reiss 1989), body size can be considered as a structural and functional constraint and comparative studies usually remove sizeeffects (Harvey and Pagel 1991). Similarly, we considered phylogenetic effects as inherited constraints. Although environmental effects may vary according to these constraints, we did not include any interaction in the model. This is mostly for technical reasons, to keep reasonable the number of parameters to be estimated in relation to sample size. Afterwards, we looked for phylogeny-environment interaction by comparing environmental effects (which include the residuals of the model) among taxonomic groups.

For the phylogenetic part, many existing comparative methods assume a Brownian motion model for the evolution of traits (which is used in many comparative methods: e.g. Felsenstein 1985, Grafen 1989). This model is appropriate for the evolution of a continuous trait under random genetic drift or fluctuating selection (Martins and Hansen 1997). Other models have been developed for evolution under stabilizing selection (Martins and Hansen 1997). These particular processes cannot be assumed for life history traits of fishes, which are poorly known from an evolutionary point of view. Therefore, without stating any evolutionary model, we made the assumption that the inherited part is 
similar between closely related species and different between distant species: following Cheverud et al. (1985) and Gittleman and Kot (1990), we defined the phylogenetic component as an autoregression. Thus the phylogenetic influence on trait variation for population $i$ is a weighted mean of the observations $y_{j}$, for $j \neq i$

$$
z_{i}=\sum_{j, j \neq i} \rho W_{i j} y_{j}
$$

The weights were chosen equal to the inverse of the path's length on the evolutionary tree. Here path's length is measured as a number of nodes rather than estimates of branch lengths. This simplification is possible because autoregressive methods are known to be robust to inaccuracies in branch lengths (Gittleman and Luh 1992, Purvis et al. 1994, Martins 1996).

Further, we focused on populations and not species, and thus we had to account for the differences between intra-specific and inter-specific variation. Because intra- and inter-specific variations do not reflect the same time scale, we split the phylogenetic component into two parts, both autoregressive:

$$
z_{i}=\sum_{j, j \neq i}\left(\rho^{(b)} W_{i j}^{(b)} y_{j}+\rho^{(w)} W_{i j}^{(w)} y_{j}\right)
$$

The superscript $(b)$ refers to the inter-specific part (between) and (w) to the intra-specific part (within). Coefficients $W_{i j}^{(b)}$ are the inverse of path's length from the species of population $i$ to the species of population $j . W_{i j}^{(w)}$ was assumed equal to unity if population $i$ and population $j$ belong to the same species and zero otherwise. Intraspecific variability was assumed constant among taxa and among environments (a single $\rho^{(w)}$ is estimated): we describe the resemblance between populations within a species by the unweighted mean of all other populations of this species.

Let us consider the environmental part. In classical models such as stated in the spatial framework (Cliff and Ord, 1981; Cheverud et al.; 1985; Gittleman and Kot; 1990), the residuals are independent and identically normally distributed (iid), that is $\varepsilon_{i} \equiv \mathrm{N}\left(\mu, \sigma^{2}\right)$, assuming that the environmental effect (plus error) is the same for all populations. Here, for the purpose of detecting fishing effects on the traits, we stated the existence of I homogeneous groups of fishing pressure, with different distributions of their residuals. Within each group, the environmental effect is iid. For instance if the population $i$ belongs to group $g(i)$, its environmental component should be written $\varepsilon_{i} \equiv \mathrm{N}\left(\mu_{g(i)}, \sigma_{g(i)}^{2}\right)$. 
The final model can be written as

$$
\begin{aligned}
& y_{i}=\sum_{j, j \neq i}\left(\rho^{(b)} W_{i j}^{(b)} y_{j}+\rho^{(w)} W_{i j}^{(w)} y_{j}\right)+L_{i} \gamma+\varepsilon_{i} \\
& \text { where } \varepsilon_{i} \equiv \mathrm{N}\left(\mu_{g(i)}, \sigma_{g(i)}^{2}\right), \\
& \text { and the population } i \text { belongs to the group } g(i) .
\end{aligned}
$$

This model is fully specified with $2 I+2+r$ parameters, $\left(\mu_{1} \Lambda \mu_{I}, \sigma_{1} \Lambda \sigma_{I}, \rho^{(b)}, \rho^{(w)}, \gamma_{1} \Lambda \gamma_{r}\right)$. Let $\mu=\left(\mu_{g(1)} \Lambda \mu_{g(n)}\right)$ and $\Sigma=\operatorname{diag}\left(\sigma_{g(1)} \Lambda \sigma_{g(n)}\right)$ be a diagonal matrix of dimension $n$. Given that $\varepsilon$ follows a multivariate normal distribution of mean $\mu$ and variance $\Sigma$, we can write the log-

likelihood

$$
\begin{aligned}
& L=\ln |B|-\frac{1}{2} \ln |\Sigma|-\frac{1}{2}(B y-\mu-L \gamma)^{\prime} \Sigma^{-1}(B y-\mu-L \gamma), \\
& \text { with } B=I d_{n}-\rho^{(b)} W^{(b)}-\rho^{(w)} W^{(w)}, \\
& \text { and }|B| \text { is the determinant of } B \text {. }
\end{aligned}
$$

To find an estimation of the parameters, we used a maximum likelihood procedure (Kendall and Stuart 1979, Cliff and Ord 1981). Further detail on model development and parameter estimation can be found in Cornillon et al. (2000).

\section{6) Selecting the best model}

The general model is a family embedding the case of phylogenetic independence $\left(\rho^{(b)}=0\right.$ and $\left.\rho^{(w)}=0\right)$ and also the classical model without fishing effect $\left(\mu_{g}=\mu, \forall g \in\{1, \ldots, I\}\right.$ and $\left.\sigma_{g}=\sigma, \forall g \in\{1, \ldots, I\}\right)$. From these observations, classical likelihood theory allows us to test every model with a likelihood ratio test. For instance to test a classical model $\left(\mu_{g}=\mu, \forall g\right.$ and $\sigma_{g}=\sigma, \forall g$ ) with $p=4+r$ parameters, $H_{0}$, against the fishing effect model $H_{1}$ with $q=2+2 I+r$ parameters, we used the difference between the log-likelihood estimated under $H_{1}\left(\mathrm{~L}_{H_{1}}\right)$ and the log-likelihood estimated under $H_{0}\left(\hat{L}_{H_{0}}\right)$. This statistic follows a Chi-square distribution with $q-p$ degrees of freedom:

$$
\lambda=2\left(\hat{\mathrm{L}}_{H_{1}}-\mathrm{L}_{H_{0}}\right) \cong \chi^{2}(q-p)
$$

If observed $\lambda$ is greater than $\chi_{1-\alpha}^{2}(q-p)$, the $(1-\alpha)^{\text {th }}$ quantile, then under $H_{0}$ the probability of an incorrect rejection of $H_{0}$ is $\alpha$, which is the size of the critical region. The test procedure is a comparison between $\lambda$ and $\chi_{1-\alpha}^{2}(q-p)$; if $\lambda$ is greater than $\chi_{1-\alpha}^{2}(q-p)$ then $H_{0}$ is rejected, otherwise $H_{0}$ is accepted. For each trait we fitted the full model (1), the following sub-models:

$$
\sigma_{g}=\sigma, \forall g
$$$$
\text { (equal variance in all groups of environment) }
$$ 


$$
\mu_{g}=\mu, \forall g \text { and } \sigma_{g}=\sigma, \forall g \quad \text { (no environmental effect, classical model) }
$$

and the corresponding models with no phylogenetic effect $\left(\rho^{(b)}=0\right.$ and $\left.\rho^{(w)}=0\right)$ and/or no size effect $(\gamma=0)$.

The best model in the likelihood sense was further tested by checking whether the residuals had a spherical shape. Plots of residuals were helpful to show phylogeny-environment interactions, and other variations not accounted for in the model.

\section{7) Applying the model to our data}

All traits were logarithmically transformed, except $\mathrm{F}_{\mathrm{b}}$ which was estimated from logarithmically transformed data.

The complete model was fitted to $\mathrm{T}_{.05}, \mathrm{~T}_{\mathrm{m}}$ and $\mathrm{F}_{\mathrm{m}}$, which are known to be highly constrained by body size. The allometric component was not estimated for $\mathrm{L}_{.05}$, the slope of the fecundity-length relationship $F_{b}$ and relative size at maturity $L_{r m}$, which are already free of size effects. Egg size is frequently correlated with female size within fish populations or species (e.g. Zijlstra 1973, Buckley et al. 1991, Roff 1992), but not across families (Elgar 1990). Optimal egg size in fish is mainly determined by factors affecting larval survival (Wootton 1994, Tyler and Sumpter 1996). Therefore, there is no reason to expect any relationship between initial and adult size (Ebenman 1992, Kozlowski 1996). In addition, egg size and $\mathrm{L}_{.05}$ are not correlated in our sample $\left(\mathrm{r}^{2}=0.045\right)$, hence we did not estimate the allometric component for egg volume.

Principal Component Analysis (PCA) (Mardia et al. 1979) was applied to the phylogenetic components of traits to search for broad evolutionary trends in life history trait combinations in teleost fishes. PCA was performed on size-corrected traits $\left(T_{.05}, T_{m}, F_{m}\right)$ plus $F_{b}$ and Egg to show these trends free of size effects. PCA was calculated from the correlation matrix to standardise for the influence of unequal variances. Relative size at maturity $\mathrm{L}_{\mathrm{rm}}$ is not included in this PCA because its phylogenetic component is not significant, nor adult size $\mathrm{L}_{.05}$ because it was used to scale other traits. We standardised this supplementary variable and projected it on the subspace spanned by the first two axes (Lebart et al. 1984); this amounts to a multiple regression on the two axes.

Fishing effects on each trait were assessed by the comparison of means and variances of the tree groups experiencing different fishing pressures. As we applied an additive model on 
logarithmically transformed data, we get a multiplicative model by the reciprocal transformation.

Fishing effects on life history traits become multiplicative coefficients, estimated by $e^{\mu_{i}+\sigma_{i}^{2} / 2}$ (mean of a log-normal distribution). Variability of fishing effects among taxonomic groups was examined by comparing the distributions of residuals within orders.

\section{Results}

Phylogeny significantly influenced patterns of variation in all traits but relative length-atmaturity. The allometric component was significant in $\mathrm{T}_{.05}, \mathrm{~T}_{\mathrm{m}}$ and $\mathrm{F}_{\mathrm{m}}$. Fishing had a significant effect on all traits but length-at-5\%-survival (Tables 1 and 2). In all traits, coefficient $\rho^{(b)}$ is larger than $\rho^{(w)}$. As expected, a larger weight is ascribed to inter-specific neighbourhood than to intra-specific neighbourhood. The relative contribution of each component to the total variability varies among traits.

PCA of phylogenetic components exhibits positive correlations of age-at-maturity with timeto-5\%-survival and egg volume, opposed to fecundity at maturity and the slope of the fecunditylength relationship, on the first axis (52\% of total variance). The second axis accounts for $23 \%$ of total variance and shows a negative correlation between fecundity-at-maturity and slope of the fecunditylength relationship (Table 3, Fig. 2A). The projection of adult size as additional variable shows that large size is associated with high fecundity at maturity. On the plot of the populations' first two components (Fig. 2B), populations belonging to the same order are well grouped. Clupeiformes, Scorpeaniformes, Salmoniformes and Argentiniformes appear on the first axis of the size-corrected analysis in order of increasing life span, age at maturity and egg volume. The second axis discriminates Clupeiformes from Perciformes, Pleuronectiformes and Gadiformes with increasing fecundity at maturity and decreasing slope of the fecundity-length relationship.

Fishing has a significant effect on six of the seven traits considered (Fig. 3). Increasing fishing pressure decreases time-to-5\%-survival, age at maturity and egg volume, and increases fecundity at maturity, slope of the fecundity-length relationship and size at maturity.

We estimated fishing effects, going back to raw data. From low to high fishing pressure age at maturity is decreased by $23 \%$ and egg size by $37 \%$ (Table 4 ). For fecundity at maturity, the effects of 
fishing on variance $\left(\sigma_{i}\right)$ associated with effects on mean $\left(\mu_{i}\right)$ resulted in trends opposite to those observed on log-transformed data: $\mathrm{F}_{\mathrm{m}}$ appears decreased by fishing when back-transformed.

Standardised residuals are spherical (regular decrease in eigenvalues of PCA of standardised residuals, not shown), suggesting a comparable goodness of fit of the selected models for all traits. To detect potential differences of fishing effects among taxonomic groups, we plotted the distribution of the environmental component within orders for each fishing pressure group. The differences are the most important for $\mathrm{F}_{\mathrm{m}}$. In Clupeiformes $\mathrm{F}_{\mathrm{m}}$ declines under fishing pressure, it is unchanged in the group of Argentiniformes and Salmoniformes, whereas it increases in other orders (Fig. 4, to be compared to Fig. 3).

\section{Discussion}

\section{Life history strategies}

After removing the effect of body size, variations in life history traits of fishes are organised along two axes. The first one, which highlights the correlation of age at maturity and adult life span, might be interpreted as a gradient of turn-over, ranking species from the fastest to the slowest. Slow species spawn relatively lower numbers of larger eggs, illustrating the trade-off between size and number of eggs, well documented among fish species (Duarte and Alcaraz 1989, Elgar 1990). In contrast, fast species spawn many tiny eggs, which is supposed to be an optimal response to a high temporal or spatial heterogeneity in resource availability (Winemiller and Rose 1993). Slow turn-over appears to have evolved among Argentiniformes and Salmoniformes, which belong to the old radiation of protacanthopterygii (lower Euteleostean: Johnson and Patterson 1996), and particular groups of higher teleosts like Scorpaeniformes. In these groups, slow turn-over and large body size are often associated with parental care (Blumer 1982). The "fast" taxonomic groups segregate on a second axis, which describes a trade-off between fecundity at maturity and slope of the fecunditylength relationship (Fig 2). All fast groups belong to neoteleosts, the group of all the fishes above protacanthopterygii, defined on the basis of skull and jaw characters that are lacking in primitive fishes (Helfman et al. 1997). 
This pattern may arise from a spurious decomposition of traits, owing to the model or to the data. In our model, we assumed no interaction between size-constraints, phylogenetic constraints and environmental effects, i.e. that fishing effects should be similar in all taxonomic groups. We checked for such interactions by examining the residual component, which is assumed to include most of variations not accounted for in the model (see below). On the other hand, because we were dependent on published data, the even distribution of the three fishing pressure groups among all branches of the phylogenetic tree is not perfect. Therefore the model may ascribe a part of fishing effects to the phylogenetic component. We cannot exclude that this happened here: the four populations of Argentines considered are weakly exploited, and play an important role on the first axis. By contrast, all cod populations examined bear intermediate to heavy exploitation, and the phylogenetic component of their life span may be underestimated compared to other taxa. However, diversely exploited populations belonging to different taxa contribute to both axes; removing Argentine populations from the PCA does not change the overall structure of the analysis (Table 3). Although we cannot claim that our sample is representative of all exploited stocks, we believe that the inclusion of phylogenetically diverse taxa from northern, temperate and tropical environments gives an unbiased picture of life history strategies in exploited fishes.

Fish life history patterns fit those found in lizards, birds and mammals (Stearns 1983, Gaillard et al. 1989, Promislow and Harvey 1990, Shine and Charnov 1992, Clobert et al. 1998). Within these groups, life history traits are organised along a first allometric gradient which ranks species along an increasing body size continuum (Western 1979, Lebreton 1981). Once this size-effect is removed, a second "slow-fast" continuum ranks species from the ones with a slow turn-over (late maturity, long life span, low fecundity) to fast species with the opposite set of traits. The third axis varies among groups. In mammals, this third axis is related to maternal investment (Pontier et al. 1993). It also exists in lizards, although it is more difficult to interpret (Clobert et al. 1998). Let us examine the third axis in fishes.

Among fast species, most teleost species segregate along a second gradient describing the schedule of reproductive effort. Clupeiformes have a lower fecundity at maturity and a higher slope of the fecundity-length relationship. On the opposite, Gadiformes relatively invest more in fecundity at maturity, but their fecundity increases less steeply with size. The other groups of neoteleosts rank 
between these two extremes. Because of the well-known trade-off between growth and reproduction (Iles 1974, Ware 1982, Roff 1983, Sibly and Calow 1987), we expect this difference in the schedule of reproductive effort to be reflected in the growth pattern. Gadiformes allocate much energy to reproduction as soon as they mature, and then increase slowly this share. Therefore, they may have a more indeterminate growth and reach a larger size than Clupeiformes, which first spawn fewer eggs but then increase steeply their fecundity, leaving less and less resources for further growth. Actually, relative size at maturity is negatively correlated with the second axis $(\mathrm{r}=-0.25, \mathrm{P}=0.02$; we used observations minus fishing effect, because the phylogenetic component of $\mathrm{L}_{\mathrm{rm}}$ is not significant). Relative size at maturity has been frequently reported to be much lower in neoteleosts than in Clupeiformes (Beverton 1963, Ware 1980, Beverton 1992). Furthermore, as expected, Gadiformes reach a larger adult size than Clupeiformes (correlation of adult size with the second axis: $r=0.74, P<10^{-4}$ ). In other groups with indeterminate growth such as snakes and lizards, relative size at maturity also decreases when 'absolute' body size increases (Andrews 1982, Shine and Charnov 1992). These findings can be interpreted in the light of theoretical predictions that increasing survival with size, or with age, should favor a more indeterminate growth (Kozlowski and Uchmanski 1987, Taylor and Gabriel 1993, Engen and Saether 1994). That mortality rate decreases with size is commonly accepted in the marine environment (Peterson and Wroblewski 1984).

The slow-fast continuum may be interpreted within the framework of Murphy's prediction (Murphy 1968) that the high and variable level of juvenile mortality relative to adult mortality should select for late maturity and long reproductive life-span (bet-hedging: Stearns 1976). Accordingly, a positive association between age at maturity, reproductive life-span and the variability of early survival has been reported within Clupeiformes (Murphy 1968, Leggett and Carscadden 1978, Powell 1994) and Salmonids (Hutchings and Morris 1985, Hutchings and Jones 1998). However, in Neoteleosts like flatfishes and Percoids, Roff (1981) and Mann and Mills (1979) did not find such evidence. Our results show that these groups belong to different gradients: the former belongs to a bet-hedging gradient, whereas the latter evolved a different schedule of resource allocation in response to environmental variability. Moreover, previous studies of fish life histories identified three strategies as endpoints of a triangular continuum: opportunistic strategists (small, early maturing, short-lived fishes like Clupeiformes), periodic strategists (larger and longer-lived fishes with high 
fecundity, e.g. Gadiformes) and equilibrium strategists (intermediate sized fishes that produce fewer but larger offspring like Salmoniformes) (Kawasaki 1980, Winemiller 1989, Winemiller and Rose 1992). These strategies can also be interpreted in our framework. The equilibrium strategists are at the slow end-point of the slow-fast continuum, whereas opportunistic and periodic strategists can be regarded as two extremes along the gradient of resource allocation schedule.

\section{Fishing effects}

Most of observed fishing effects are in accordance with theoretical predictions. Obviously, increasing fishing pressure is strongly associated with decreasing time-to- $5 \%$-survival. More interestingly, apart from $\mathrm{T}_{.05}$, the traits with the highest fishing effects (i.e. the highest contribution of this component to its variance) are age at maturity (decreased by fishing) and fecundity at maturity (increased). For the latter, effects of fishing are opposite when considering estimated effects on logarithmically transformed traits, or direct effects by the reverse transformation. This discrepancy may be due to differences in fishing effects among taxonomic groups (see below), leading to high variances within each fishing pressure group. As expected, exploited fishes compensate for high adult mortality by maturing earlier and increasing their early reproduction (Reznick 1993). Earlier maturity under fishing pressure is well documented (e.g. Schaffer and Elson 1975, Beacham 1983, Haug and Tjemsland 1986, Jorgensen 1990, Trippel 1995). Changes in fecundity at maturity have not been previously reported because authors usually do not consider this trait. However, reexamination of data from single stock studies of North Sea plaice (Horwood et al. 1986) and sole (Rijnsdorp et al. 1991) indicates that fecundity at maturity increased under exploitation. Fishing also increases the slope of the fecundity-length relationship, accelerating the increase in reproductive investment in the course of individual life, in accordance with results from single stock studies (Kelly and Stevenson 1985, Armstrong et al. 1989).

Increasing fishing pressure also results in decreased egg size. The most simple hypothesis to explain this effect is that fishing affects age structure. In fishes, younger females have smaller eggs (Zijlstra 1973, Mann and Mills 1979, Hislop 1988, Buckley et al. 1991, Powell 1994, Kjesbu et al. 1996, see review in Trippel et al. 1997): a higher proportion of younger females taking part in reproduction should decrease egg size. An alternative hypothesis is the trade-off between egg size and number 
(Roff 1992), which has been demonstrated within populations of different species of Clupeiformes (Mann and Mills 1979, Blaxter and Hunter 1982, Tanasichuk and Ware 1987), Salmoniformes (Bromage et al. 1990, Beacham and Murray 1993) and North Sea plaice (Rijnsdorp 1991). Increase in food supply, possibly due to reduced density, may cause smaller offspring to be optimal (Sibly 1991); while, when stock size increases, the competition between post-larvae makes fewer numbers of larger eggs more suitable (Rijnsdorp 1991).

We find that fishing increases relative size at maturity. This is expected when considering regulation mechanisms (Reznick 1993). However, in the long term, size-selective fishing and increased adult mortality should select for a lower size at maturity. The expected opposite effects of regulation mechanisms and selection may be a reason for the weak effect estimated here, and for the contradictory results previously reported: depending on populations, length at maturity increases (de Veen 1976), decreases (Hempel 1978, Beacham 1983, Bowering 1989, Rijnsdorp 1989, Rowell 1993, Clark and Tracey 1994) or remains unchanged (Pitt 1975, Haug and Tjemsland 1986).

Unexpectedly, we are not able to show any fishing effect on length-at-5\%-survival. This may be due to opposite consequences of direct effect of fishing, regulation mechanisms and selective pressure. Removal of larger individuals reduces the mean individual size in the population and acts as a selective pressure to smaller sizes. In addition, fishing mortality reduces time-to-5\% survival and then the age at which adult size is measured. On the other hand, reduced density will release growth and yield increased size at all ages.

Fishing decreases age at maturity, time-to-5\%-survival and egg size, the traits which are positively correlated with the first axis of the PCA of size corrected phylogenetic components, and increases $\mathrm{F}_{\mathrm{b}}$ and $\mathrm{F}_{\mathrm{m}}$ (negatively correlated with this axis). As expected, increased adult mortality caused by fishing shifts life history trait combinations towards the fast end of the slow-fast continuum

\section{Do fishing effects depend on phylogeny?}

Examination of fishing effects at the ordinal level reveals differences among orders. Clupeiformes and protacanthopterygii do not compensate for high adult mortality by increasing their fecundity at maturity. Accordingly, within several Clupeiformes populations, the increased egg 
production associated with decreased density does not occur in the smaller size-classes, but rather by a steeper increase of fecundity with size (Kelly and Stevenson 1985, Armstrong et al. 1989). This increased fecundity compensates only partially for the reduction in stock caused by fishing (Bridger 1961, Schopka and Hempel 1973, Ware 1985, Fiedler et al. 1986, review of 11 collapsed stocks in Beverton 1990, Powell 1994). Similarly, in Salmonids and Osmeridae, fecundity is often found to be weakly density-dependent (Usahkov and Galkin 1983, Velikanov 1987, Chigbu and Sibley 1994, Huse and Gjoesaeter 1997) and the variations in egg-production caused by fluctuations in population size are only partially moderated by density-dependence (van Densen 1979). By contrast, in Pleuronectiformes such as North Sea sole and plaice, and Gadiformes like cod, losses due to exploitation are compensated for by increased fecundity at maturity and thereafter (de Veen 1976, Horwood et al. 1986, Rijnsdorp 1991, Rijnsdorp et al. 1991).

The trait with the highest difference among taxa is the one with inconsistent effects of fishing when estimating them on log-transformed data or when going back to raw data. This suggests that our additive model might not be suitable for this trait. Further developments of comparative analyses should involve models including a phylogeny-environment interaction term.

Although we are not able to quantify this interaction, our results permit the conclusion that responses to fishing differ among higher taxa. Clupeiformes and protacanthopterygii compensate less in reproduction than other groups. Clupeiformes have deserved special management considerations, mainly because they are short-lived. Because they have high turn-over rates and a high colonising power, they have been thought to undergo higher fishing mortality rates than other species: fishing mortality rates proportional to M have often been recommended (Beddington and Cooke 1983, Gulland 1983, Patterson 1992). We accounted for this while defining fishing pressure groups, because we scaled fishing mortality to natural mortality. However, many stock collapses have involved clupeoids. Similarly, many stocks of protacanthopterygii are declining or extinct for a mixture of reasons, including overexploitation, for example capelin and smelts (Tjelmeland and Bogstad 1993, Maitland and Lyle 1996), Pacific (Nehlsen et al. 1991) and Atlantic salmons (Parrish et al. 1998). In these groups growth and size have varied under exploitation, by either selection or densitydependence (Schaffer and Elson 1975, Handford et al. 1977, Ricker 1981, McAllister et al. 1992, Hutchings 1993, Chigbu and Sibley 1994, Ricker 1995). The observed changes in reproduction are 
under the influence of changes in growth: density-dependence in fecundity is mostly attributable to the dependence of fecundity on size (van Densen 1979, Healey and Heard 1984, Chigbu and Sibley 1994, Huse and Gjoesaeter 1997); in Salmonids age and size at maturity are strongly related to growth (Schaffer and Elson 1975, Healey 1986, Randall et al. 1986, Helle and Hoffman 1998). Reproductive advantages of a large parental body size favour late maturation (Schaffer and Elson 1975, Riddell 1986) and as a consequence, age at maturity remains unchanged even under long-term heavy exploitation (Hegge et al. 1991). We suggest that lower flexibility in age, size and fecundity at maturity may cause these taxa to have lower resilience to exploitation. By contrast, the higher resilience of neoteleosts may be associated with their more indeterminate growth, which is suspected to allow a larger potential of phenotypic modulation in the allocation of resources to growth and reproduction (Jokela and Mutikainen 1995).

In conclusion, we find that fishes life history strategies are organised along two nonallometric axes, like other Vertebrates studied so far: a slow-fast continuum, and a gradient in the schedule of resource allocation into growth and reproduction. At the origin of both axes, Clupeiformes are a group of small opportunistic fishes that invest into reproduction at the cost of growth. This strategy has a low potential to compensate in reproduction for fishing mortality and therefore a low resilience. However, their high potential population growth rate allows Clupeiformes to rebuild large biomasses when conditions are favourable. There are two ways of becoming large despite environmental variability. According to the bet-hedging theory, a group of larger long-lived animals laying larger eggs and exhibiting parental care evolved along the slow-fast continuum. These K-strategists are vulnerable to exploitation because their strategy relies on a long life span and will be affected by increased adult mortality. The other choice was to cope with environmental variability by the continued allocation of energy into growth after sexual maturity. This indeterminate growth allows them to reach a large size; the associated plasticity of both growth and reproduction gives them a higher resilience to environmental variability, including fishing mortality. This may explain why higher teleosts sometimes display large biomass in the seas even while heavily exploited. 
These patterns may be refined by including more populations or other traits. For example, we did not include semelparous species that exist among protacanthopterygii, nor neoteleosts species with reduced fecundity associated with diverse kinds of parental care.

The effects of fishing estimated from this study may happen by direct effects, by population regulation mechanisms, or by evolution. We are not able to disentangle these causes from the present data. Disentangling evolved effects from phenotypic plasticity is an urgent task to properly take these changes into account in stock assessment and management.

\section{Acknowledgements}

We thank Guillaume Lecointre for help in collating phylogenetic information, and JeanDominique Lebreton for helpful discussions during the course of the work. Jean Clobert, Jean-Michel Gaillard, Philippe Gros, Simon Jennings and Nigel Yoccoz and an anonymous referee provided valuable comments on previous versions of this paper.

\section{References}

Andrews, R. M. 1982. Patterns of growth in reptiles. In: Gans, C. and Pough, F. H. (eds), Biology of the Reptilia, 13, Academic Press, pp. 273-320.

Aota, A. and Ikemura, T. 1986. Diversity in G+C content at the third position of codons in vertebrate genes and its cause. - Nucleic Acids Res. 14: 6345-6355.

Armstrong, M. J., Roel, B. A. and Prosch, R. M. 1989. Long-term trends in patterns of maturity in the southern Benguela pilchard population: evidence for density-dependence? - S. Afr. J. mar. Sci. 8: 91-101.

Bauwens, D. and Diaz-Uriarte, R. 1997. Covariation of life history traits in lacertid lizards: a comparative study. - Am. Nat. 149: 91-111.

Beacham, T. D. 1983. Variability in median size and age at sexual maturity of Atlantic Cod, Gadus morhua, on the Scotian Shelf in the Northwest Atlantic Ocean. - Fish. Bull. 81: 303-321. 
Beacham, T. D. and Murray, C. B. 1993. Fecundity and egg size variation in North American Pacific salmon (Oncorhynchus). - J. Fish Biol. 42: 485-508.

Beddington, J. R. and Cooke, J. G. 1983. The potential yield of fish stocks. - FAO Fisheries Technical Paper 242: 47.

Beverton, R. J. H. 1963. Maturation, growth and mortality of Clupeid and Engraulid stocks in relation to fishing. - Rapports et Procès-Verbaux du Conseil international pour l'Exploration de la Mer 154: 44-67.

Beverton, R. J. H. 1990. Small marine pelagic fish and the threat of fishing; are they endangered? - J. Fish Biol. 37: 5-16.

Beverton, R. J. H. 1992. Patterns of reproductive strategy parameters in some marine teleost fishes. - J. Fish Biol. 41: 137-160.

Beverton, R. J. H. and Holt, S. J. 1957. On the dynamics of exploited fish populations. - Fishery Investigations, Series II, 19, Her Majesty's Stationery Office.

Beverton, R. J. H. and Holt, S. J. 1959. A review of the life-span and mortality rates in nature, and their relation to growth and other physiological characteristics. - Ciba Found. Colloq. Ageing 5: $142-177$.

Björklund, M. 1997. Are 'comparative methods' always necessary? - Oikos 80: 607-612.

Blaxter, J. H. S. and Hunter, J. R. 1982. The biology of the Clupeoid Fishes. - Adv. Mar. Biol. 20: 1-223.

Blumer, L. S. 1982. A bibliography and categorization of bony fishes exhibiting parental care. Zoolog. J. Linn. Soc. 76: 1-22.

Boake, C. R. B. 1994. Quantitative genetic studies of behavioral evolution. - University of Chicago Press.

Borisov, V. M. 1979. The selective effect of fishing on the population structure of species with a long life cycle. - Journal of Ichthyology 18: 896-904.

Bowering, W. R. 1989. Witch flounder distribution off Southern Newfoundland, and changes in age, growth, and sexual maturity patterns with commercial exploitation. - Trans. Am. Fish. Soc. 118: 659-669.

Bridger, J. P. 1961. On fecundity and larval abundance of Downs herrings. - Fishery Investigations Series II 23. 
Britten, R. J. 1986. Rates of DNA sequence evolution differ between taxonomic groups. - Science 231: 1393-1398.

Bromage, N., Hardiman, P., Jones, J., Springate, J. and Bye, V. 1990. Fecundity, egg size and total egg volume differences in twelve stocks of rainbow trout, Oncorhynchus mykiss Richardson. Aquaculture and Fish. Managem. 21: 269-284.

Brower, A. V. Z., DeSalle, R. and Vogler, A. 1996. Gene trees, species trees, and systematics: a cladistic perspective. - Annual Review in Ecology and Systematics 27: 423-450.

Buckley, L. J., Smigielski, A. S., Halavik, T. A., Caldarone, E. M., Burns, B. R. and Laurence, G. C. 1991. Winter flounder Pseudopleuronectes americanus reproductive success. II. Effects of spawning time and female size on size, composition and viability of eggs and larvae. - Mar. Ecol. Prog. Ser. 74: 125-135.

Catzeflis, F. M., Sheldon, F. H., Ahlquist, J. E. and Sibley, C. G. 1987. DNA-DNA hybridization evidence of the rapid rate of muroid rodent DAN evolution. - Mol. Biol. Evol. 4: 242-253.

Charlesworth, B. 1994. Evolution in age structured populations. - Cambridge Studies in Mathematical Biology, Cambridge University Press.

Cheverud, J. M., Dow, M. M. and Leutenegger, W. 1985. The quantitative assessment of phylogenetic constraints in comparative analyses: Sexual dimorphism in body weights among primates. Evolution 39: 1335-1351.

Chigbu, P. and Sibley, T. H. 1994. Relationship between abundance, growth, egg size and fecundity in a landlocked population of longfin smelt, Spirinchus thaleichthys. - J. Fish Biol. 45: 1-15.

Clark, M. R. and Tracey, D. M. 1994. Changes in a population of orange roughy, Hoplostethus atlanticus, with commercial exploitation on the Challenger Plateau, New Zealand. - Fish. Bull. 92: 236-253.

Cliff, A. D. and Ord, J. K. 1981. Spatial processes: models and applications. - Pion.

Clobert, J., Garland, T. and Barbault, R. 1998. The evolution of demographic tactics in lizards: a test of some hypotheses concerning life history evolution. - J. Evol. Biol. 11: 329-364.

Cornillon, P.-A., Pontier, D. and Rochet, M. J. 2000. Autoregressive models for estimating phylogenetic and environmental effects: accounting for within-species variations. - J. Theor. Biol. 202: 247-256. 
Cushing, D. H. 1981. Fisheries biology. A study in population dynamics. - The University of Wisconsin Press.

de Veen, J. F. 1976. On changes in some biological parameters in the North Sea sole. - J. Cons. int. Explor. Mer 37: 60-90.

Duarte, C. M. and Alcaraz, M. 1989. To produce many small or few large eggs: a size-independent reproductive tactic of fish. - Oecologia 80: 401-404.

Ebenman, B. 1992. Evolution in organisms that change their niches during the life cycle. - Am. Nat. 139: 990-1021.

Elgar, M. A. 1990. Evolutionary compromise between a few large and many small eggs: comparative evidence in teleost fish. - Oikos 59: 283-287.

Engen, S. and Saether, B.-E. 1994. Optimal allocation of resources to growth and reproduction. Theor. Popul. Biol. 46: 232-248.

Eschmeyer, W. N. 1990. Catalog of the genera of recent fishes. - California Academy of Sciences.

Felsenstein, J. 1985. Phylogenies and the comparative method. - Am. Nat. 125: 1-15.

Fiedler, P. C., Methot, R. D. and Hewitt, R. P. 1986. Effects of California El Niño 1982-1984 on the northern anchovy. - Journal of Marine Research 44: 317-338.

Foster, S. A. and Cameron, S. A. 1996. Geographic variation in behavior: a phylogenetic framework for comparative studies. In: Martins, E. P. (ed.), Phylogenies and the comparative method in animal behaviour, Oxford University Press, .

Frank, K. T. and Leggett, W. C. 1994. Fisheries ecology in the context of ecological and evolutionary theory. - Annu. Rev. Ecol. Syst. 25: 401-422.

Fulton, T. W. 1891. The comparative fecundity of sea-fishes. - Annual Report of the Fishery Board for Scotland 9: 243-268.

Gadgil, M. and Bossert, W. H. 1970. Life historical consequences of natural selection. - Am. Nat. 104: $1-24$.

Gaillard, J. M., Festa-Bianchet, M. and Yoccoz, N. G. 1998. Population dynamics of large herbivores: variable recruitment with constant adult survival. - Trends Ecol. Evol. 13: 58-63.

Gaillard, J. M., Pontier, D., Allaine, D., Lebreton, J. D., Trouvilliez, J. and Clobert, J. 1989. An analysis of demographic tactics in birds and mammals. - Oikos 56: 59-76. 
Gittleman, J. L. and Kot, M. 1990. Adaptation: statistics and a null model for estimating phylogenetic effects. - Syst. Zoolog. 39: 227-241.

Gittleman, J. L. and Luh, H.-K. 1992. On comparing comparative methods. - Annu. Rev. Ecol. Syst. 23: 383-404.

Grafen, A. 1989. The phylogenetic regression. - Phil. Trans. R. Soc. Lond. B 326: 119-157.

Gulland, J. A. 1983. Fish stock assessment. - John Wiley \& Sons.

Gunderson, D. R. 1997. Trade-off between reproductive effort and adult survival in oviparous and viviparous fishes. - Can. J. Fish. Aquat. Sci. 54: 990-998.

Gunderson, D. R. and Dygert, P. H. 1988. Reproductive effort as a predictor of natural mortality rate. J. Cons. int. Explor. Mer 44: 200-209.

Handford, P., Bell, G. and Reimchen, T. 1977. A gillnet fishery considered as an experiment in artificial selection. - J. Fish. Res. Board Can. 34: 954-961.

Harvey, P. H. and Pagel, M. D. 1991. The comparative method in evolutionary biology. - Oxford Series in Ecology and Evolution, Oxford University Press.

Haug, R. and Tjemsland, J. 1986. Changes in size- and age-distributions and age at sexual maturity in Atlantic halibut, Hippoglossus hippoglossus, caught in North Norwegian waters. - Fish. Res. 4: 145-155.

Healey, M. C. 1986. Optimum size and age at maturity in Pacific Salmon and effects of size-selective fisheries. - Can. Spec. Publ. Fish. Aquat. Sci. 89: 39-52.

Healey, M. C. and Heard, W. R. 1984. Inter- and intra-population variation in the fecundity of chinook salmon (Oncorhynchus tshawytscha) and its relevance to life history theory. - Can. J. Fish. Aquat. Sci. 41: 476-783.

Hegge, O., Dervo, B. K. and Skurdal, J. 1991. Age and size at sexual maturity of heavily exploited arctic charr and brown trout in lake Atnsjø, Southeastern Norway. - Trans. Am. Fish. Soc. 120: 141-149.

Helfman, G. S., Collette, B. B. and Facey, D. E. 1997. The diversity of fishes. - Blackwell Science.

Helle, J. H. and Hoffman, M. S. 1998. Changes in size and age at maturity of two North American stocks of chum salmon (Oncorhynchus keta) before and after a major regime shift in the North Pacific Ocean. - North Pacific Anadromous Fish Committee Bulletin 1: 81-89. 
Hempel, G. 1978. North sea fisheries and fish stocks - a review of recent changes. - Rapp. P.V. Réun. Cons. int. Explor. Mer 173: 145-167.

Hislop, J. R. G. 1988. The influence of maternal length on the size and weight of the eggs and the relative fecundity of the haddock, Melanogrammus aeglefinus, in British waters. - J. Fish Biol. 32: 923-930.

Hoenig, J. M. 1983. Empirical use of longevity data to estimate mortality rates. - Fish. Bull. 82: 898-903.

Horwood, J. W., Bannister, R. C. A. and Howlett, G. J. 1986. Comparative fecundity of North Sea plaice (Pleuronectes platessa L.). - Proc. R. Soc. Lond. B 228: 401-431.

Huse, G. and Gjoesaeter, H. 1997. Fecundity of the Barents Sea capelin (Mallotus villosus). - Marine Biology 130: 309-313.

Hutchings, J. A. 1993. Reaction norms for reproductive traits in brook trout and their influence on life history evolution affected by size-selective harvesting. - In Stokes T.K., McGlade J.M. and Law R. (Eds). The exploitation of evolving resources. Lecture Notes in Biomathematics, 99, Springer-Verlag, Berlin : 107-125.

Hutchings, J. A. and Jones, M. E. B. 1998. Life history variation and growth rate thresholds for maturity in Atlantic salmon, Salmo salar. - Can. J. Fish. Aquat. Sci. 55, Supplement 1: 22-47.

Hutchings, J. A. and Morris, D. W. 1985. The influence of phylogeny, size and behaviour on patterns of covariation in salmonid life histories. - Oikos 45: 118-124.

Iles, T. D. 1974. The tactics and strategy of growth in fishes. In: Harden Jones, F. R. (ed.), Sea Fisheries Research, Elek Science, pp. 331-345.

Jennings, S. and Beverton, R. J. H. 1991. Intraspecific variation in the life history tactics of Atlantic herring stocks. - ICES J. mar. Sci. 48: 117-125.

Jennings, S. and Kaiser, M. J. 1998. The effects of fishing on marine ecosystems. - Adv. Mar. Biol. 34: 201-351.

Jennings, S., Reynolds, J. D. and Mills, S. C. 1998. Life history correlates of responses to fisheries exploitation. - Proc. R. Soc. Lond. B 265: 333-339.

Johnson, G. D. and Patterson, C. 1996. Relationships of lower Euteleostean fishes. In: Stiassny, M. L. J., Parenti, L. R., and Johnson, G. D. (eds), Interrelationships of fishes, Academic Press, pp. 251- 
Jokela, J. and Mutikainen, P. 1995. Phenotypic plasticity and priority rules for energy allocation in a freshwater clam: a field experiment. - Oecologia 104: 122-132.

Jones, R. 1989. Towards a general theory of population regulation in marine teleosts. - J. Cons. int. Explor. Mer 45: 176-189.

Jorgensen, T. 1990. Long-term changes in age at sexual maturity of Northeast Arctic cod (Gadus morhua L.). - J. Cons. int. Explor. Mer 46: 235-248.

Kawasaki, T. 1980. Fundamental relations among the selections of life history in the marine teleosts. Bulletin of the Japanese Society of Scientific Fisheries 46: 289-293.

Kelly, K. H. and Stevenson, D. K. 1985. Fecundity of Atlantic herring (Clupea harengus) from three spawning areas in the Western Gulf of Maine, 1969 and 1982. - J. Northw. Atl. Fish. Sci. 6: 149155.

Kendall, M. and Stuart, A. 1979. The advanced theory of statistics. - 2, Charles Griffin \& Co.

Kirkpatrick, M. 1993. The evolution of size and growth in harvested natural populations. In: Stokes, T. K., McGlade, J. M., and Law, R. (eds), The exploitation of evolving resources. Lecture Notes in Biomathematics, 99, Springer-Verlag, pp. 145-154.

Kjesbu, O. S., Solemdal, P., Bratland, P. and Fonn, M. 1996. Variation in annual egg production in individual captive Atlantic cod (Gadus morhua). - Can. J. Fish. Aquat. Sci. 53: 610-620.

Knight, W. 1968. Asymptotic growth: an example of nonsense disguised as mathematics. - J. Fish. Res. Board Can. 25: 1303-1307.

Kozlowski, J. 1996. Optimal initial size and adult size of animals: consequences for macroevolution and community structure. - Am. Nat. 147: 101-114.

Kozlowski, J. and Uchmanski, J. 1987. Optimal individual growth and reproduction in perennial species with indeterminate growth. - Evol. Ecol. 1: 214-230.

Law, R. 1979. Optimal life histories under age-specific predation. - Am. Nat. 114: 399-417.

Law, R. and Rowell, C. A. 1993. Cohort-structured populations, selection responses, and exploitation of the North Sea cod. In: Stokes, T. K., McGlade, J. M., and Law, R. (eds), The exploitation of evolving resources. Lecture Notes in Biomathematics, 99, Springer-Verlag, pp. 155-173.

Lebart, L., Morineau, A. and Warwick, K. M. 1984. Multivariate descriptive statistical analysis. Correspondence analysis and related techniques for large matrices. - Wiley, New York, . 
Lebreton, J. D. 1981. Contribution à la dynamique des populations d'oiseaux. Modèles mathématiques en temps discret. Thèse d'Etat, Université Claude Bernard Lyon I. p.

Lecointre, G. 1994. Aspects historiques et heuristiques de l'ichtyologie systématique. - Cybium 18: 339430.

Leggett, W. C. and Carscadden, J. E. 1978. Latitudinal variation in reproductive characteristics of American shad (Alosa sapidissima): evidence for population specific life history strategies in fish. - J. Fish. Res. Board Can. 35: 1469-1478.

Li, W. H., Ellsworth, D. L., Krushkal, J., Chang, B. H. J. and Hewett-Emett, D. 1996. Rate of nucleotide substitution in Primates and rodents and the generation-time hypothesis. - Mol. Phyl. Evol. 5: 182-187.

Lynch, M. 1991. Methods for the analysis of comparative data in evolutionary biology. - Evolution 45: 1065-1080.

Maitland, P. S. and Lyle, A. A. 1996. The smelt Osmerus eperlanus in Scotland. - Freshwater Forum 6: 57-68.

Mann, R. H. K. and Mills, C. A. 1979. Demographic aspects of fish fecundity. In: Miller, P. J. (ed.), Fish phenology: anabolic adaptiveness in teleosts. Symposia of the Zoological Society of London, 44, Academic Press, pp. 161-177.

Mann, R. H. K., Mills, C. A. and Crisp, D. T. 1984. Geographical variation in the life-history tactics of some species of freshwater fish. In: Potts, G. W. and Wootton, R. J. (eds), Fish reproduction: strategies and tactics, Academic Press, pp. 171-186.

Mardia, K. V., Kent, J. T. and Bibby, J. M. 1979. Multivariate analysis. - Academic Press.

Martins, E. 1996. Phylogenies, spatial autoregression, and the comparative method: a computer simulation test. - Evolution 50: 1750-1765.

Martins, E. P. and Hansen, T. F. 1997. Phylogenies and the comparative method: A general approach to incorporating phylogenetic information into the analysis of interspecific data. - Am. Nat. 149: 646-667.

McAllister, M. K., Peterman, R. M. and Gillis, D. M. 1992. Statistical evaluation of a large-scale fishing experiment designed to test for a genetic effect of size-selective fishing on British Columbia pink salmon (Oncorhynchus gorbuscha). - Can. J. Fish. Aquat. Sci. 49: 1294-1304. 
McCann, K. and Shuter, B. 1997. Bioenergetics of life history strategies and the comparative allometry of reproduction. - Can. J. Fish. Aquat. Sci. 54: 1289-1298.

McKenzie, W. D. J., Crews, D., Kallman, K. D., Policanski, D. and Sohn, J. J. 1983. Age, weight and the genetics of sexual maturation in the platyfish, Xiphophorus maculatus. - Copeia 1983: 770-774.

McNamara, J. M. and Houston, A. I. 1996. State-dependent life histories. - Nature 380: 215-221.

Michod, R. E. 1979. Evolution of life histories in response to age-specific mortality factors. - Am. Nat. 113: 531-550.

Mindell, D. P. and Thacker, C. E. 1996. Rates of molecular evolution: phylogenetic issues and applications. - Annu. Rev. Ecol. Syst. 27: 279-303.

Murphy, G. I. 1968. Pattern in life history and the environment. - Am. Nat. 102: 391-403.

Nehlsen, W., Williams, J. E. and Lichatowich, J. A. 1991. Pacific salmon at the crossroads: stocks at risk from California, Oregon, Idaho, and Washington. - Fisheries 16: 4-21.

Nelson, J. S. 1994. Fishes of the world. - John Wiley \& Sons.

Nelson, K. and Soulé, M. 1987. Genetical conservation of exploited fishes. In: Ryman, N. and Utter, F. (eds), Population genetics and fisheries management, Washington Sea Grant, pp. 345-368.

Parrish, D. L., Behnke, R. J., Gephard, S. R., McCormick, S. D. and Reeves, G. H. 1998. Why aren't there more Atlantic salmon (Salmo salar)? - Can. J. Fish. Aquat. Sci. 55, Supplement 1: 281-287.

Patterson, K. 1992. Fisheries for small pelagic species: an empirical approach to management targets. Reviews in Fish Biology and Fisheries 2: 321-338.

Pauly, D. 1980. On the interrelationships between natural mortality, growth parameters, and mean environmental temperature in 175 fish stocks. - J. Cons. int. Explor. Mer 39: 175-192.

Peterson, I. and Wroblewski, J. S. 1984. Mortality rate of fishes in the pelagic ecosystem. - Can. J. Fish. Aquat. Sci. 41: 1117-1120.

Pitt, T. K. 1975. Changes in abundance and certain biological characteristics of Grand Bank American Plaice, Hippoglossoides platessoides. - J. Fish. Res. Board Can. 32: 1383-1398.

Pontier, D., Gaillard, J. M. and Allainé, D. 1993. Maternal investment per offspring and demographic tactics in placental mammals. - Oikos 66: 424-430. 
Powell, A. B. 1994. Life history traits of two allopatric Clupeids, Atlantic Menhaden and Gulf Menhaden, and the effects of harvesting on these traits. - North American Journal of Fisheries Management 14: 53-64.

Promislow, D. E. L. and Harvey, P. H. 1990. Living fast and dying young: a comparative analysis of life-history variation among mammals. - J. Zoolog. 220: 417-437.

Purvis, A., Gittleman, J. L. and Luh, H.-K. 1994. Truth or consequences: effects of phylogenetic accuracy on two comparative methods. - J. Theor. Biol. 167: 293-300.

Raitt, D. S. 1932. The fecundity of the Haddock. - Fisheries, Scotland, Sci. Invest. I.

Randall, T. G., Thorpe, J. E., Gibson, R. J. and Reddin, D. G. 1986. Biological factors affecting age at maturity in Atlantic Salmon (Salmo salar). - Can. Spec. Publ. Fish. Aquat. Sci. 89: 90-96.

Reiss, M. J. 1989. The allometry of growth and reproduction. - Cambridge University Press.

Reznick, D. N. 1993. Norms of reaction in fishes. In: Stokes, T. K., McGlade, J. M., and Law, R. (eds), The exploitation of evolving resources. Lecture Notes in Biomathematics, 99, Springer-Verlag, pp. 72-90.

Reznick, D. N., Rodd, F. H. and Cardenas, M. 1996. Life-history evolution in guppies (Poecilia reticulata: Poeciliidae). IV. Parallelism in life-history phenotypes. - Am. Nat. 147: 319-338.

Ricker, W. E. 1981. Changes in the average size and average age of Pacific Salmon. - Can. J. Fish. Aquat. Sci. 38: 1636-1656.

Ricker, W. E. 1995. Trends in the average size of Pacific salmon in Canadian catches. In: Beamish, R. J. (ed.), Climate change and northern fish populations. Can. Spec. Publ. Fish. Aquat. Sci., 121, pp. 593-602.

Riddell, B. E. 1986. Assessment of selective fishing on the age at maturity in Atlantic Salmon (Salmo salar): a genetic perspective. - Can. Spec. Publ. Fish. Aquat. Sci. 89: 102-109.

Rijnsdorp, A. D. 1989. Maturation of male and female North Sea plaice (Pleuronectes platessa L.). - J. Cons. int. Explor. Mer 46: 35-51.

Rijnsdorp, A. D. 1991. Changes in fecundity of female North Sea plaice (Pleuronectes platessa L.) between three periods since 1900. - ICES J. mar. Sci. 48: 253-280. 
Rijnsdorp, A. D. 1993. Fisheries as a large-scale experiment on life-history evolution: disentangling phenotypic and genetic effects in changes in maturation and reproduction of North Sea plaice, Pleuronectes platessa L. - Oecologia 96: 391-401.

Rijnsdorp, A. D. 1994. Population-regulating processes during the adult phase in flatfish. - Neth. J. Sea Res. 32: 207-223.

Rijnsdorp, A. D., Daan, N., van, B., F.A. and Heessen, H. J. L. 1991. Reproductive variability in North Sea plaice, sole, and cod. - J. Cons. int. Explor. Mer 47: 352-375.

Rijnsdorp, A. D. and van Leeuwen, P. I. 1992. Density-dependent and independent changes in somatic growth of female North Sea plaice Pleuronectes platessa between 1930 and 1985 as revealed by back-calculation of otoliths. - Mar. Ecol. Prog. Ser. 88: 19-32.

Roff, D. A. 1981. Reproductive uncertainty and the evolution of iteroparity: why don't flatfish put all their eggs in one basket? - Can. J. Fish. Aquat. Sci. 38: 968-977.

Roff, D. A. 1982. Reproductive strategies in flatfish: a first synthesis. - Can. J. Fish. Aquat. Sci. 39: 16861698.

Roff, D. A. 1983. An allocation model of growth and reproduction in fish. - Can. J. Fish. Aquat. Sci. 40: 1395-1404.

Roff, D. A. 1984. The evolution of life history parameters in teleosts. - Can. J. Fish. Aquat. Sci. 41: 9891000.

Roff, D. A. 1991. The evolution of life-history variation in fishes, with particular reference to flatfish. Neth. J. Sea Res. 27: 197-207.

Roff, D. A. 1992. The evolution of life histories: theory and analysis. - Chapman and Hall.

Rowell, C. A. 1993. The effects of fishing on the timing of maturity in North Sea cod (Gadus morhua L.). In: Stokes, T. K., McGlade, J. M., and Law, R. (eds), The exploitation of evolving resources. Lecture Notes in Biomathematics, 99, Springer-Verlag, pp. 44-61.

Schaffer, W. M. 1974. Selection for optimal life histories: the effects of age structure. - Ecology 55: 291303.

Schaffer, W. M. and Elson, P. F. 1975. The adaptive significance of variations in life history among local populations of atlantic salmon in North America. - Ecology 56: 577-590. 
Schopka, S. A. and Hempel, G. 1973. The spawning potential of populations of herring (Clupea harengus L.) and cod (Gadus morhua L.) in relation to the rate of exploitation. In: Parrish, B. B. (ed.), Fish stocks and recruitment. Rapports et Procès-verbaux des Réunions du Conseil international pour l'Exploration de la Mer, 164, pp. 178-185.

Shine, R. and Charnov, E. L. 1992. Patterns of survival, growth, and maturation in snakes and lizards. - Am. Nat. 139: 1257-1269.

Shine, R. and Iverson, J. B. 1995. Patterns of survival, growth, and maturation in turtles. - Oikos 72: 343-348.

Sibly, R. M. 1991. The life-history approach to physiological ecology. - Funct. Ecol. 5: 184-191.

Sibly, R. M. and Calow, P. 1987. Growth and resource allocation. In: Calow, P. (ed.), Evolutionary physiological ecology, Cambridge University Press, pp. 37-52.

Sparholt, H. 1990. Improved estimates of the natural mortality rates of nine commercially important fish species included in the North Sea Multispecies VPA model. - J. Cons. int. Explor. Mer 46: 211-223.

Stearns, S. C. 1976. Life-history tactics: a review of the ideas. - Q. Rev. Biol. 51: 3-47.

Stearns, S. C. 1983. The influence of size and phylogeny on patterns of covariation among life-history traits in the mammals. - Oikos 41: 173-187.

Stearns, S. C. 1992. The evolution of life histories. - Oxford University Press.

Stokes, T. K., McGlade, J. M. and Law, R., eds. 1993. The exploitation of evolving resources. - Lecture Notes in Biomathematics, 99, Springer-Verlag.

Svensson, E. 1997. The speed of life-history evolution. - Trends Ecol. Evol. 12: 380-381.

Tanasichuk, R. W. and Ware, D. M. 1987. Influence of interannual variations in winter sea temperature on fecundity and egg size in Pacific herring (Clupea harengus pallasi). - Can. J. Fish. Aquat. Sci. 44: 1485-1495.

Taylor, B. E. and Gabriel, W. 1993. Optimal adult growth of Daphnia in a seasonal environment. Funct. Ecol. 7: 513-521.

Tjelmeland, S. and Bogstad, B. 1993. The Barents sea capelin stock collapse: a lesson to learn. - Can. Spec. Publ. Fish. Aquat. Sci. 120: 127-139.

Trippel, E. A. 1995. Age at maturity as a stress indicator in fisheries. - Bioscience 45: 759-771. 
Trippel, E. A., Kjesbu, O. S. and Solemdal, P. 1997. Effects of adult age and size structure on reproductive output in marine fishes. In: Chambers, R. C. and Trippel, E. A. (eds), Early life history and recruitment in fish populations. Fish and Fisheries Series, 21, Chapman and Hall, pp. 29-62.

Tyler, C. R. and Sumpter, J. P. 1996. Oocyte growth and development in teleosts. - Reviews in Fish Biology and Fisheries 6: 287-318.

Usahkov, N. G. and Galkin, A. S. 1983. Stock composition and dynamics of abundance of the Barents Sea capelin, Biologiya i promysel pelagicheskikh ryb severnogo bassejna, Sb. Nauch. Tr. Pinro., pp. 100-115.

van Densen, W. L. T. 1979. The fecundity of the smelt, Osmerus eperlanus L., in the Tjeukemeer. - Neth. J. Zool. 29: 623.

Velikanov, A. Y. 1987. Fecundity of the Far East capelin, Mallotus villosus socialis, in the coastal water of Sakhalin. - J. Ichthyol. 27: 87-96.

von Bertalanffy, L. 1934. Untersuchungen über die Gesetzlichkeit des Wachtums. I. Allgemeine Grundlagen der Theorie, mathematische und physiologische Gesetzlichkeiten des Wachstums bei Wassertieren. - Wilhelm Roux Archiv für EntwickelungsMechanik der Organismen 131: 613-652.

Ware, D. M. 1980. Bioenergetics of stock and recruitment. - Can. J. Fish. Aquat. Sci. 37: 1012-1024.

Ware, D. M. 1982. Power and evolutionary fitness of Teleosts. - Can. J. Fish. Aquat. Sci. 39: 3-13.

Ware, D. M. 1985. Life history characteristics, reproductive value, and resilience of Pacific herring (Clupea harengus pallasi). - Can. J. Fish. Aquat. Sci. 42: 127-137.

Western, D. 1979. Size, life history and ecology in mammals. - Journal of African Ecology 17: 185-204.

Winemiller, K. O. 1989. Patterns of variations in life history among South American fishes in seasonal environments. - Oecologia 81: 225-241.

Winemiller, K. O. and Rose, A. 1992. Patterns of life-history diversification in North American fishes: implications for population regulation. - Can. J. Fish. Aquat. Sci. 49: 2196-2218.

Winemiller, K. O. and Rose, K. A. 1993. Why do most fish produce so many tiny offspring? - Am. Nat. 142: 585-603. 
Wootton, R. J. 1979. Energy costs of egg production and environmental determinants of fecundity in Teleost fishes. In: Miller, P. J. (ed.), Fish phenology: anabolic adaptiveness in teleosts. Symposia of the Zoological Society of London, 44, Academic Press, pp. 133-159.

Wootton, R. J. 1994. Life histories as sampling devices: optimum egg size in pelagic fishes. - J. Fish Biol. 45: 1067-1077.

Zammuto, R. M. 1986. Life histories of birds: Clutch size, longevity and body mass among North American game birds. - Can. J. Zoolog. 64: 2739-2749.

Zijlstra, J. J. 1973. Egg weight and fecundity in the North sea herring (Clupea harengus). - Neth. J. Sea Res. 6: 173-204. 


\begin{tabular}{ccccccccc}
\hline Model & $\mathbf{T}_{\mathbf{m}}$ & $\mathbf{L}_{\mathbf{m}}$ & $\mathbf{T}_{.05}$ & $\mathbf{F}_{\mathbf{m}}$ & $\mathbf{L}_{.05}$ & $\mathbf{F}_{\mathbf{b}}$ & Egg & $\mathbf{L}_{\mathrm{rm}}$ \\
\hline $\mathbf{( 3 )}$ & 22.7511 & & 9.329 & -93.8646 & & & & \\
$\mathbf{( 2 )}$ & $\mathbf{2 6 . 9 7 0 8}$ & & $\mathbf{2 9 . 7 7 4 3}$ & -87.8801 & & & & \\
$\mathbf{( 1 )}$ & 27.6739 & & 29.9714 & -76.173 & & & & \\
\hline $\mathbf{( 2 A )}$ & 20.7888 & & 23.6030 & -92.2327 & & & & \\
$\mathbf{( 1 A )}$ & 23.6947 & & 23.6809 & -83.7879 & & & & \\
\hline $\mathbf{( 3 B )}$ & 5.7583 & $\mathbf{9 . 6 2 4 8}$ & -1.8535 & -95.0724 & 7.106 & -31.3302 & -28.261 & 108.4602 \\
$\mathbf{( 2 B )}$ & 7.6317 & 13.1765 & 4.2 & -90.8223 & 9.0122 & -29.0561 & -25.0187 & 112.5790 \\
$\mathbf{( 1 B )}$ & 8.0134 & 14.8326 & 4.7162 & -79.2468 & 11.2232 & -21.5842 & -24.7403 & 118.5358 \\
\hline $\mathbf{( 2 C )}$ & -13.2911 & -7.3018 & -11.6948 & -98.4356 & -12.6086 & -32.4796 & -65.4564 & 108.2367 \\
$\mathbf{( 1 C )}$ & -12.8621 & -4.4243 & -11.1997 & -92.6142 & 9.7453 & -25.0946 & -63.4564 & $\mathbf{1 1 6 . 7 1 4 0}$ \\
\hline
\end{tabular}

Table 1. Log-likelihood of nested models for life-history traits: (1) full model; (2) $\sigma_{g}=\sigma, \forall g ;(3)$ $\mu_{g}=\mu, \forall g$ and $\sigma_{g}=\sigma, \forall g$; (nA) no phylogenetic component; (nB) no allometric component; (nC) no phylogenetic nor allometric component. Threshold value for the difference between two nested models: $\frac{1}{2} \chi_{3,0.95}^{2}=3.91$. Threshold value for the difference between models with and without phylogenetic component: $\frac{1}{2} \chi_{2,0.95}^{2}=3.00$. Threshold value for the difference between models with and without allometric component: $\frac{1}{2} \chi_{1,0.95}^{2}=1.92$. Bold: selected model. 


\begin{tabular}{|c|c|c|c|c|c|c|c|c|c|}
\hline & $\rho^{(w)}$ & $\rho^{(\mathbf{b})}$ & $\mu_{1}$ & $\mu_{2}$ & $\mu_{3}$ & $\gamma$ & $\sigma_{1}$ & $\sigma_{2}$ & $\sigma_{3}$ \\
\hline $\mathbf{T}_{\mathrm{m}}$ & 0.1886 & 0.3281 & 0.1762 & 0.0110 & -0.1478 & 0.6409 & 0.4427 & & \\
\hline$\underline{L}_{\mathrm{rm}}$ & & & -0.0547 & -0.0003 & 0.0479 & & 0.2189 & 0.1697 & 0.0994 \\
\hline$T_{.05}$ & 0.1848 & 0.3049 & 0.4038 & 0.0418 & -0.4405 & 0.6775 & 0.4275 & & \\
\hline $\mathbf{F}_{\mathrm{m}}$ & 0.2828 & 1.0177 & -1.2102 & 0.2517 & 0.4367 & 0.6711 & 2.7247 & 1.3239 & 1.2114 \\
\hline $\mathbf{L}_{.05}$ & 0.4392 & 0.5086 & 3.527 & & & & 0.5462 & & \\
\hline$F_{b}$ & 0.1077 & 0.4773 & -0.2721 & -0.1331 & 0.2154 & & 0.6899 & 0.6117 & 1.187 \\
\hline Egg & 0.4262 & 0.8434 & 0.4260 & 0.1628 & 0.0530 & & 0.8323 & & \\
\hline
\end{tabular}

Table 2. Estimated values for the parameters for the selected models. Hatched: parameters which are not considered in the selected model. 


\begin{tabular}{lcccccc}
\hline & \multicolumn{3}{c}{ All populations $(\mathrm{N}=\mathbf{8 4})$} & \multicolumn{3}{c}{ Without Argentines (N=80) } \\
\hline & PC1 & PC2 & PC3 & PC1 & PC2 & PC3 \\
\hline \% Variance & 51.8 & 23.3 & 12.9 & 35.2 & 27.0 & 19.1 \\
\hline \multicolumn{2}{l}{ Variable loadings } & & & & & \\
$\mathbf{T}_{\mathbf{m}}$ & 0.497 & 0.335 & 0.427 & 0.624 & 0.222 & 0.236 \\
$\mathbf{T}_{.05}$ & 0.530 & -0.112 & 0.393 & 0.480 & -0.266 & 0.616 \\
$\mathbf{F}_{\mathbf{m}}$ & -0.290 & 0.730 & 0.378 & 0.008 & 0.767 & 0.186 \\
$\mathbf{F}_{\mathbf{b}}$ & -0.329 & -0.564 & 0.706 & -0.410 & -0.383 & 0.552 \\
$\mathbf{E g g}$ & 0.529 & -0.153 & -0.149 & 0.459 & -0.380 & -0.475 \\
\hline
\end{tabular}

Table 3. PCA statistics for the phylogenetic parts of life history traits, including Argentine populations or not. 
Relative effect of moderate fishing

\begin{tabular}{lll} 
& Relative effect of moderate fishing & Relative effect of high fishing \\
\hline $\mathbf{T}_{\mathbf{m}}$ & 0.94 & 0.77 \\
$\mathbf{L}_{\mathrm{rm}}$ & 1.05 & 1.09 \\
$\mathbf{T}_{.05}$ & 0.71 & 0.43 \\
$\mathbf{F}_{\mathbf{m}}$ & 0.25 & 0.26 \\
$\mathbf{E g g}$ & 0.73 & 0.63 \\
\hline $\mathbf{F}_{\mathrm{b}}$ & 0.14 & 0.49 \\
\hline
\end{tabular}

Table 4. Relative effect of fishing: ratios of the multiplicative coefficients due to the fishing pressure groups. From low to moderate fishing pressure: $e^{\mu_{2}+\frac{\sigma_{2}^{2}}{2}} / e^{\mu_{1}+\frac{\sigma_{1}^{2}}{2}}$; from low to high fishing pressure: $e^{\mu_{3}+\frac{\sigma_{3}^{2}}{2}} / e^{\mu_{1}+\frac{\sigma_{1}^{2}}{2}}$. For $\mathrm{F}_{\mathrm{b}}$, which was not log-transformed, the relative effect of fishing is the difference between the coefficients: . $\mu_{2}-\mu_{1}$ and $\mu_{3}-\mu_{1}$. 


\section{Figure legends}

Figure 1. Phylogenetic relationships among the orders analysed, with the numbers of populations within them. Clupeiformes are given as an example of infra-order relationships, with the level of fishing pressure to which each population is submitted. 1: low; 2: intermediate; 3 : high fishing pressure. Branch lengths, based on the number of nodes necessary to permit insertion of any new population without changing distances in the whole tree, are those used to construct phylogenetic distances. The complete phylogenetic tree can be found on web-site http://www.ifremer.fr/maerha.

Figure 2. Standardized principal component analysis of the phylogenetic parts of five life history traits.

A) Plot of the original variables on the first two principal axes. Grey: projection of adult size as additional variable.

B) The first two principal components of populations. Each population is connected to the mean value of its order. 1: Clupeiformes; 2: Argentiniformes; 3: Salmoniformes; 4: Gadiformes; 5: Lophiiformes; 6: Atheriniformes; 7: Perciformes; 8: Pleuronectiformes; 9: Scorpaeniformes.

Figure 3. Fishing effect on size-corrected demographic traits: estimated mean $\left(\mu_{\mathrm{i}}\right)$ and its asymptotic confidence interval for the groups of fishing pressure. 1: low fishing mortality, lower than natural mortality, $\mathrm{F} / \mathrm{M}<1 ; 2$ : moderate fishing pressure, $1 \leq \mathrm{F} / \mathrm{M}<2 ; 3$ : high fishing pressure, $\mathrm{F} / \mathrm{M} \geq 2$.

Figure 4. Distribution of the residuals ( $\left.\varepsilon_{i}\right)$ of fecundity at maturity (corrected for size effects) within fishing pressure groups for the most important groups. White line: median. Shaded box: interquartile range. Whiskers: full range. Protacanthopterygii include Salmoniformes and Argentiniformes. 

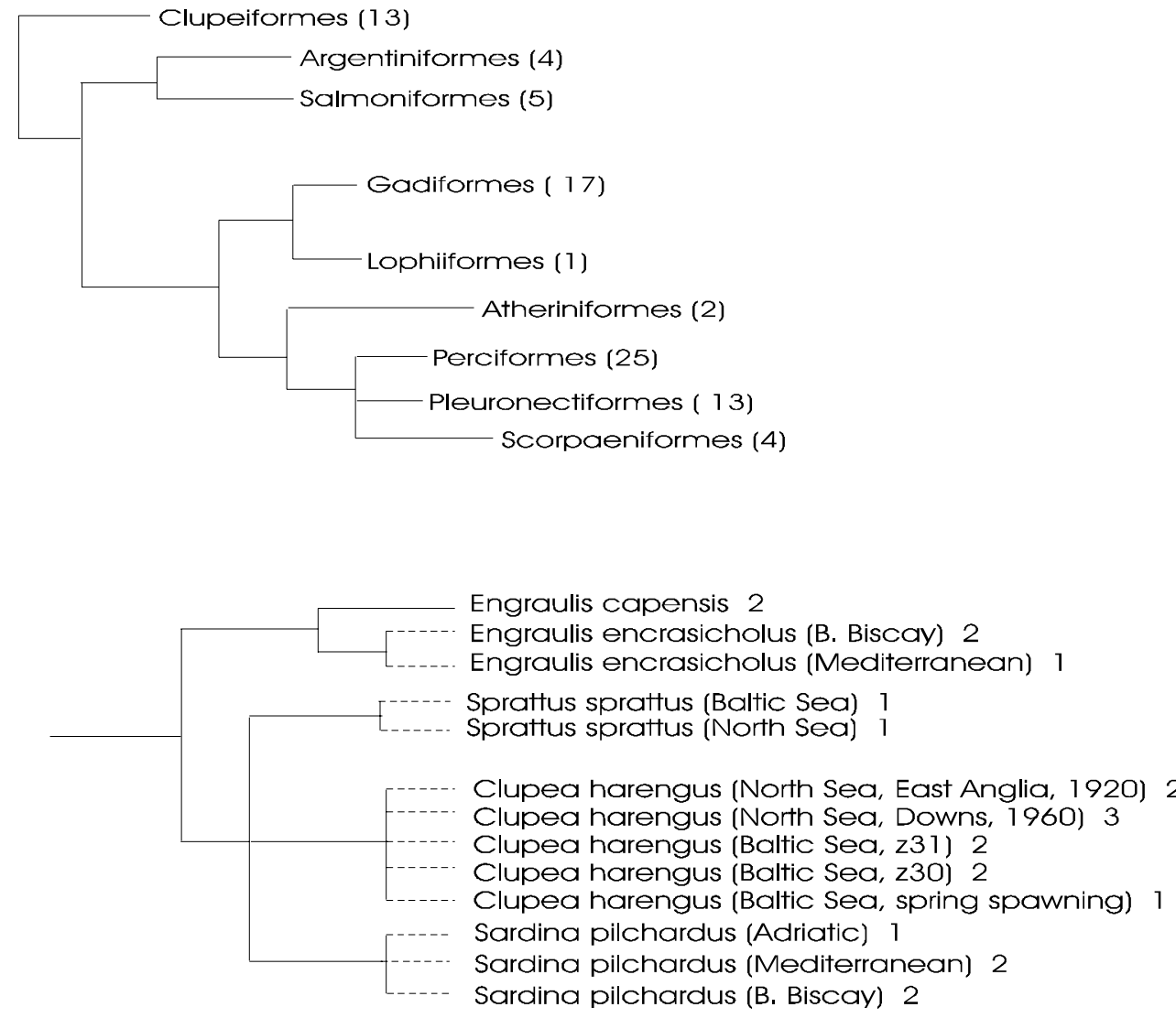

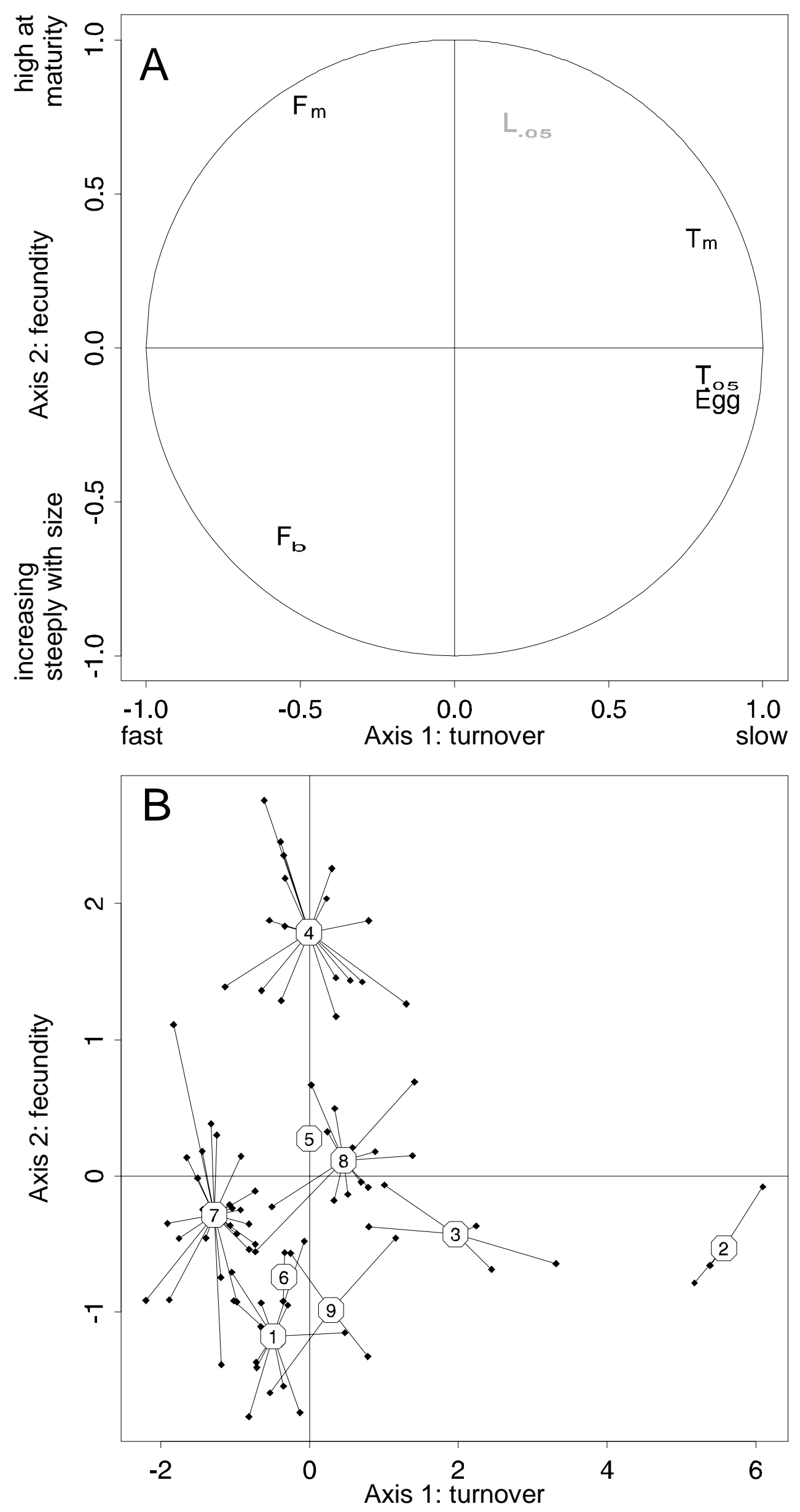

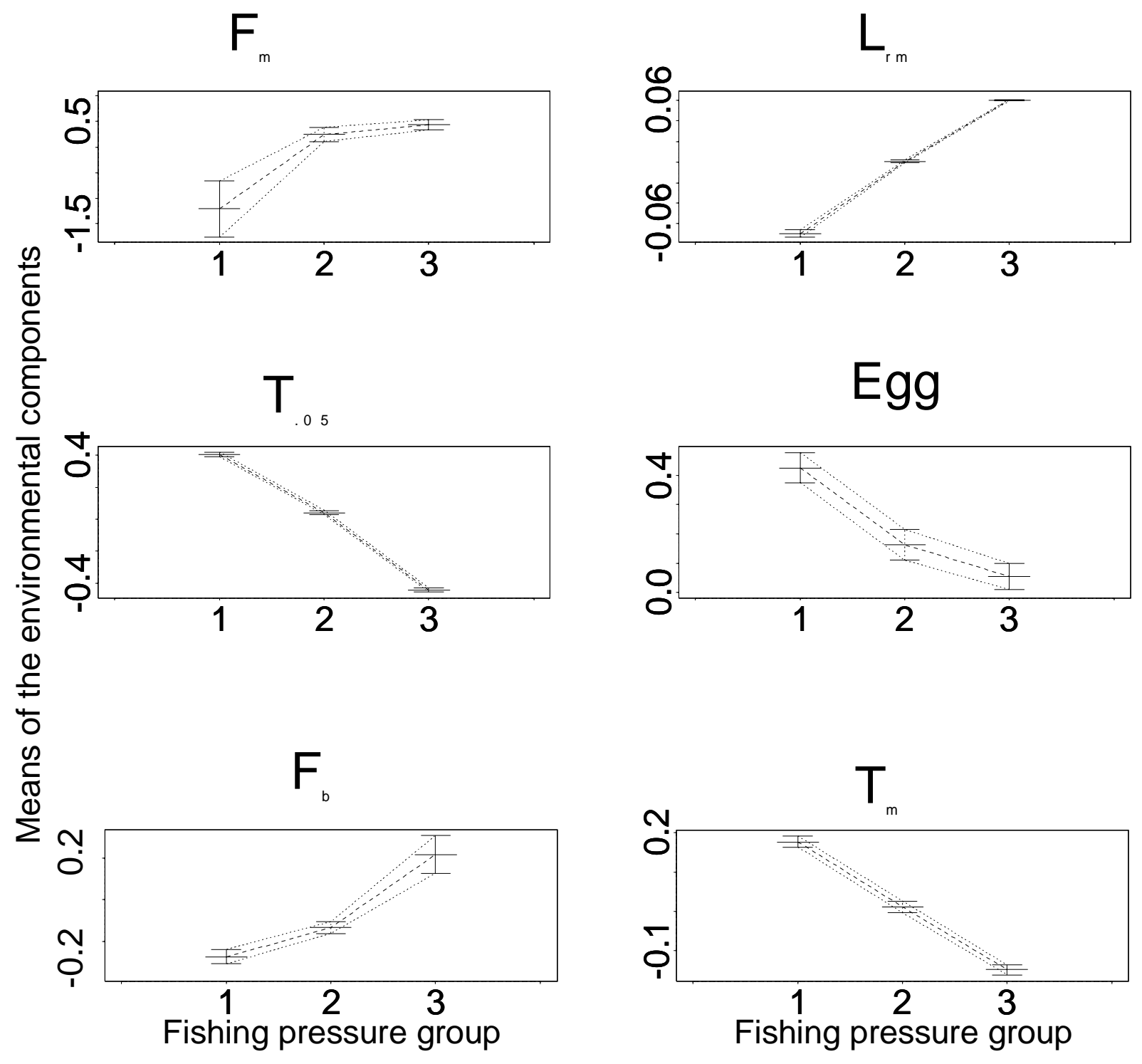

Egg
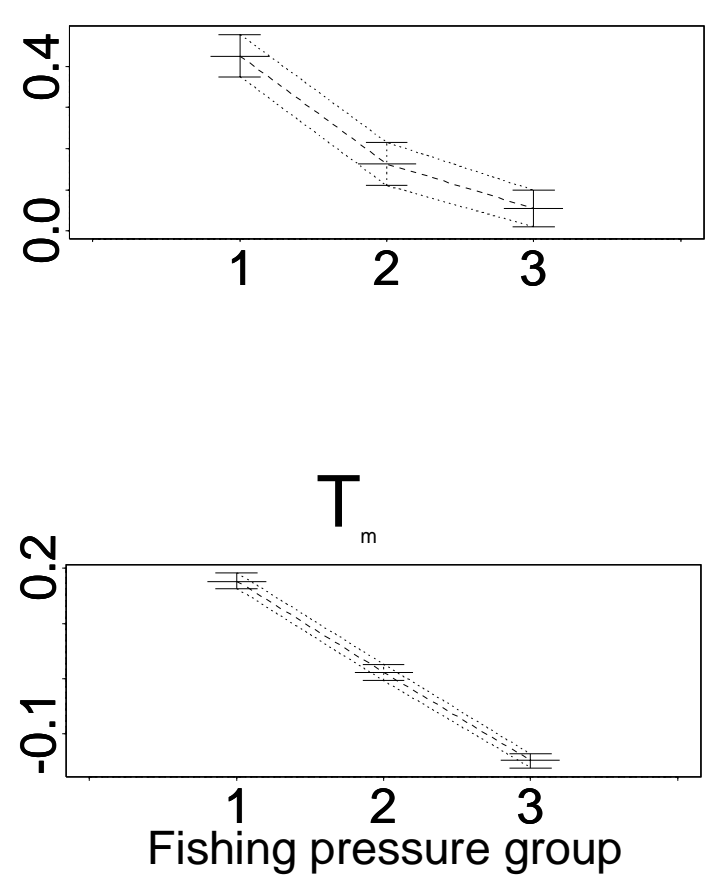

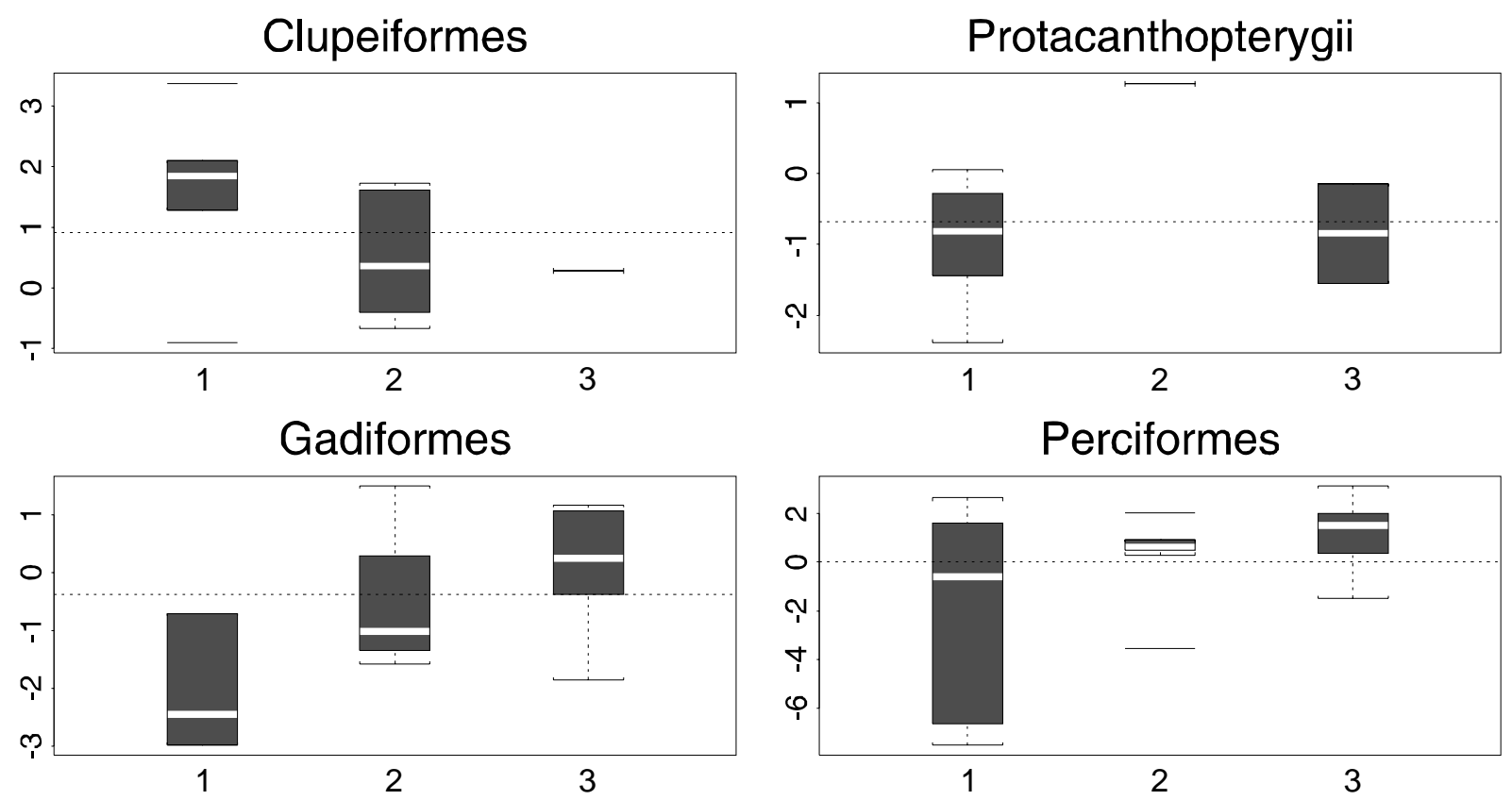

Pleuronectiformes

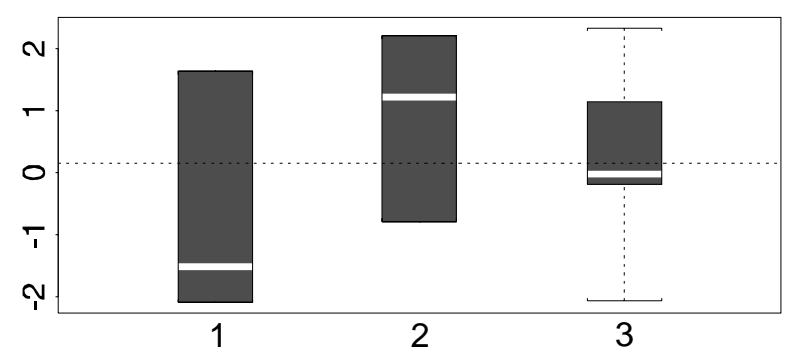

Fishing pressure group 